\title{
PENGARUH AUDITOR SPESIALISASI INDUSTRI DAN REDFLAGS TERHADAP KUALITAS LABA PADA PERUSAHAAN PUBLIK DI BIDANG KEUANGAN
}

\author{
Titi Purbo Sari, SE., M.Si. ${ }^{1}$ \\ Linda Novasari, SE., MM. ${ }^{2}$
}

\author{
Fakultas Ekonomi, Program Studi Akuntansi, Universitas Semarang \\ titipurbosari78@gmail.com ${ }^{1}$
}

Diterima: November 2018. Disetujui: Desember 2018. Dipublikasikan: Januari 2019

\begin{abstract}
Accounting cases that occurred in Indonesia have reached a very alarming level, thus giving effect on the decrease of trust to integrity and earnings quality from financial report. Therefore, the scandal makes discourse in this research to know how to detect deviations of financial statement presentation through the use of services auditor industry specialization and identify warning signs as redflags. So with the role of auditor industry specialization and redflags can contribute to the quality of the relevant and good earnings. The sample of this research consists of 121 public companies in the field of finance and listed in Indonesia Stock Exchange in 2014 - 2015. Measurement of influence of auditor industry specialization using Craswell method and measurement on redflags factor using financial ratios F-Score Model, while the earnings quality in this research proxied to the absolute level of discretionary accruals. This research uses multiple regression technique to analyze data. The results showed that simultaneously auditor industry specialization and redflags have a significant effect to earnings quality. However, if tested partially, auditors industry specialization do not significantly influence the quality of earnings while redflags have a significant effect on the quality of financial statements. This is because the financial management of each company is under strict supervision by Bank Indonesia, so that the auditor industry specialization has little role in creating good profit quality.
\end{abstract}

Keywords: Auditor industry specialization, Red Flags, Earnings Quality, Financial Industry

\begin{abstract}
ABSTRAK
Kasus akuntansi yang terjadi di Indonesia telah mencapai tingkat yang sangat memprihatinkan, sehingga memberikan efek pada menurunnya kepercayaan terhadap integritas dan earnings quality dari laporan keuangan.Oleh karena itu, skandal tersebut menjadikan wacana dalam penelitian ini untuk mengetahui cara mendeteksi penyimpangan penyajian laporan keuangan melalui penggunaan jasa auditor spesialisasi industri dan mengidentifikasi tanda - tanda peringatan sebagai redflags. Sehingga dengan adanya peranan auditor spesialisasi industri dan redflags dapat memberikan kontribusi terhadap kualitas laba yang relevan dan baik. Sampel penelitian ini terdiri dari 121 perusahaan publik di bidang keuangan dan terdaftar dalam Bursa Efek Indonesia pada tahun 2014 - 2015. Pengukuran pengaruh auditor spesialisasi industri menggunakan metode Craswell dan pengukuran pada faktor redflags menggunakan rasio keuangan F-Score Model, sedangkan kualitas laba dalam penelitian ini diproksikan dengan tingkat absolut akrual diskresioner. Penelitian ini menggunakan tehnik regresi berganda untuk menganalisis data. Hasil penelitian menunjukkan bahwa secara simultan auditor spesialisasi industri dan redflags berpengaruh signifikan terhadap kualitas laba. Namun apabila diuji secara parsial, auditor spesialisasi industri tidak berpengaruh secara signifikan terhadap kualitas laba sedangkan redflags berpengaruh signifikan terhadap kualitas laporan keuangan. Hal ini disebabkan karena manajemen keuangan setiap perusahaan berada dalam pengawasan yang ketat oleh Bank Indonesia, sehingga adanya auditor spesialisasi industri kurang berperan dalam menciptakan kualitas laba yang baik.
\end{abstract}

Kata kunci : Auditor spesialisasi industri, Red Flags, Kualitas Laba, Industri Keuangan 


\section{PENDAHULUAN}

Kasus kecurangan pelaporan keuangan di Indonesia sendiri juga terjadi pada perusahaan besar berskala nasional, seperti PT. Telkom, PT. Kimia Farma, PT. Semen Gresik, Bank Syariah Mandiri dan Bank Lippo. Kasus akuntansi tersebut memberikan bukti tentang kegagalan audit yang memberikan efek pada menurunnya kepercayaan terhadap integritas dan earnings quality dari laporan keuangan.

Kualitas informasi keuangan yang disajikan oleh manajemen perusahaan sering diasosiasikan sebagai kualitas laba. Konsep kualitas laba tidak dapat diamati sebab kualitas laba tidak memiliki definisi dalam literatur, sehingga dalam beberapa penelitian diproksikan dengan tingkat absolut akrual diskresioner (Discretionary Accruals). Oleh sebab itu, akrual diskresioner menjadi media untuk pengukuran manajemen laba. Dechow, et al. (2011) telah menggunakan pendekatan baru untuk menguji dan mendeteksi manajemen laba dengan menggabungkan pembalikan akrual. Pendekatan ini menghasilkan solusi untuk meningkatkan daya pengujian dan mengurangi misspecification dalam pengukuran manajemen laba melalui kerangka kerja yang fleksibel.

Pengungkapan pelaporan keuangan yang disajikan secara wajar dan bersih dari kecurangan dilakukan oleh pihak yang berkompeten, yaitu auditor. Setiap auditor memiliki kemampuan yang berbeda dalam mendeteksi kecurangan yang disebabkan karena beberapa faktor, misalnya tingkat pengalaman auditor yang berbeda, sikap skeptis yang berbeda dan situasi yang harus dihadapi auditor dalam bekerja. Pengalaman juga akan mempengaruhi sensitivitas auditor terhadap gejala-gejala (symptoms) kecurangan. Auditor yang berpengalaman akan memiliki pengetahuan tentang kekeliruan dan kecurangan yang lebih banyak dibandingkan dengan auditor yang tidak berpengalaman (Sucipto, 2007).

Skanda - skandal akuntansi nasional tersebut dapat dijadikan sebagai pengalaman dan pelajaran yang bermanfaat dalam mengidentifikasi tanda - tanda peringatan akuntansi sebagai red flags dengan mendeteksi potensi masalah awalnya. Petunjuk adanya indikasi kecurangan umumnya ditunjukkan dengan munculnya gejala-gejala 
(symptoms) yang tercermin melalui timbulnya karakteristik tertentu atau yang biasa dikenal dengan red flags (fraud indicators), baik yang merupakan kondisi atau keadaan lingkungan maupun perilaku seseorang (Anggriawan, 2014).

Timbulnya red flags tidak selalu menjadi indikasi adanya kecurangan, namun red flags ini biasanya muncul di setiap kasus kecurangan yang terjadi. Pemahaman dan analisis lebih lanjut terhadap red flags tersebut dapat membantu langkah selanjutnya untuk memperoleh bukti awal atau mendeteksi adanya kecurangan.

Berdasarkan pada pemikiran tersebut di atas, agar catatan akuntansi dan informasi keuangan yang disajikan bebas dari kekeliruan (unintentional misstatements) maupun kecurangan, maka penelitian ini mengembangkan dan menguji kembali secara ilmiah suatu relevansi antara pengaruh auditor spesialisasi industri dan red flags terhadap kualitas laba (earnings quality) pada perusahaan publik di bidang keuangan.

Tujuan penelitian untuk mendapatkan bukti empiris mengenai :

1. Pengelompokkan auditor spesialisasi industri dengan auditor non-spesialisasi industri dan perusahaan publik keuangan yang terindikasi red flags.

2. Pengaruh auditor spesialisasi industri dan red flags dalam memberikan kontribusi terhadap kualitas laba yang relevan dan baik.

\section{TINJAUAN PUSTAKA}

\section{Teori Keagenan (Agency Theory)}

Teori Keagenan (Agency Theory) yang dikemukakan oleh Jensen dan Meckling (1976) mendefinisikan hubungan keagenan merupakan suatu kontrak antara dua pihak yang memuat pendelegasian pekerjaan dan wewenang oleh pihak pertama (sebagai principal/ leader) kepada pihak kedua (sebagai agent/ subordinate) agar pihak kedua bersedia melakukan pekerjaan tersebut untuk kepentingan pihak pertama. Kepentingan pihak pertama selaku pihak pemegang saham dan stakeholder umumnya bertentangan dengan pihak kedua, sebab pihak pertama sebagai pengguna informasi (user) memperoleh informasi yang asimetris dari pihak kedua sebagai penyedia informasi (prepaper) yang menimbulkan adanya ketidakpastian (Deegan, 2007). 
Hal ini menyebabkan pihak agent yang terkait langsung dengan transaksi bisnis cenderung untuk melakukan perilaku yang tidak semestinya (disfunctional behaviour), antara lain dengan memanipulasi data dalam laporan keuangan agar dapat menyajikan laba sesuai harapan pihak principal, sehingga prediksi laba tersebut tidak menggambarkan kondisi perusahaan yang sebenarnya (Scott, 2009).

Kompetensi auditor dapat mengurangi tingkat manajemen laba suatu perusahaan, dan pengguna informasi laporan keuangan akan lebih mempercayai informasi yang disajikan, sehingga dapat mengurangi informasi asimetri antara pihak manajemen dengan pihak stakeholders. Jadi, teori keagenan menjelaskan mengenai kedudukan auditor sebagai pihak ketiga yang menjembatani antara principal dan agent untuk memahami konflik kepentingan yang muncul.

\section{Financial Shenanigans}

Financial Shenanigans diperkenalkan oleh Schilit sebagai suatu tindakan penggunaan akuntansi kreatif atau kelalaian dengan tujuan untuk menyembunyikan atau memanipulasi kinerja keuangan atau kondisi keuangan suatu entitas dengan mengelola laba melalui penambahan laba di tahun berjalan atau menggeser laba tahun berjalan ke periode berikutnya. Shenanigans cenderung berada pada perusahaan yang tidak melakukan check and balances dalam manajemen senior dan auditor gagal dalam mendeteksi red flags, namun perusahaan cenderung berusaha meyakinkan investor untuk mempercayai kondisi keuangan perusahaan yang terlihat stabil (Schilit dan Perler, 2010).

Tindakan manipulasi laba yang digunakan oleh manajemen perusahaan sebagai gimmick akuntansi bertujuan untuk memberikan hasil yang sesuai dengan harapan agar menaikkan harga saham dan kompensasi eksekutif menjadi lebih tinggi. Jadi dalam teori financial shenanigans, auditor di tuntut waspada kemungkinan adanya red flags yang bertujuan untuk menyembunyikan atau memanipulasi posisi keuangan, kondisi keuangan dan arus kas perusahaan.

\section{Auditor Spesialisasi Industri}

Auditor melakukan general audit (opinion audit) sebagai pelaksanaan tugas audit yang dilakukan secara independen dan obyektif. Namun, meskipun demikian dalam 
mendeteksi kecurangan bukan sepenuhnya tanggung jawab dari auditor, melainkan tanggung jawab manajemen perusahaan untuk mencegah timbulnya fraud dalam manipulasi laporan keuangan.

Auditor yang berpengalaman akan memiliki pengetahuan tentang kekeliruan dan kecurangan yang lebih banyak dibandingkan dengan auditor yang tidak berpengalaman (Sucipto, 2007). Beberapa penelitian menggunakan metode Craswell untuk mengidentifikasi auditor spesialisasi industri, sebab metode ini memiliki hasil sensitif terhadap perubahan market share untuk mengidentifikasi auditor spesialisasi industri (Sonnier dan Carson, 2009).

Beberapa penelitian menggunakan metode ini untuk mengidentifikasi auditor spesialisasi industri, sebab metode ini memiliki hasil sensitif terhadap perubahan market share untuk mengidentifikasi auditor spesialisasi industri (Sonnier dan Carson, 2009). Perhitungan metode Craswell didasarkan pada :

a. Total pendapatan klien yang diaudit dalam satu tahun dengan ketentuan auditor spesialisasi industri memiliki persentase total pendapatan klien lebih dari $15 \%$.

b. Persentase jumlah klien yang diaudit dalam satu tahun dengan ketentuan auditor spesialisasi industri memiliki persentase jumlah klien lebih dari $15 \%$.

\section{Redflags}

Petunjuk adanya indikasi kecurangan umumnya ditunjukkan dengan munculnya gejala-gejala (symptoms) yang tercermin melalui timbulnya karakteristik tertentu atau yang biasa dikenal dengan red flags (fraud indicators), baik yang merupakan kondisi atau keadaan lingkungan maupun perilaku seseorang (Anggriawan, 2014). Timbulnya red flags tidak selalu menjadi indikasi adanya kecurangan, namun red flags ini biasanya muncul di setiap kasus kecurangan yang terjadi.

Pemahaman dan analisis lebih lanjut terhadap red flags tersebut dapat membantu langkah selanjutnya untuk memperoleh bukti awal atau mendeteksi adanya kecurangan. Penelitian ini menggunakan Fraud Score Model atau lebih dikenal dengan F-Score Model sebagai langkah awal dalam mendeteksi kemungkinan adanya manipulasi pelaporan keuangan. 
Model ini telah digunakan oleh Dechow, Ge, Larson dan Sloan (2007) untuk mengidentifikasi masalah di akrual, piutang, persediaan, penjualan tunai, pendapatan dan penerbitan saham. Apabila indeks $F-$ Score $>1$, maka ada indikasi dalam perusahaan terdapat redflags, yang artinya perusahaan memiliki masalah dalam pelaporan keuangan.

\section{Kualitas Laba}

Dalam konsensus di Harvard Business School terdapat perbedaan pendapat yang mendalam mengenai definisi dan pengukuran konsep kualitas laba yang menyebabkan terdapat beberapa definisi yang saling tumpang tindih. Dichev, Graham dan Rajgopal (2012) berpendapat bahwa klasifikasi dari kualitas laba adalah laba yang berkesinambungan, berulang, konsisten, bebas dari item yang membuat laba menjadi tidak berkelanjutan, mampu memprediksi laba di masa depan dan didukung dengan arus kas yang sebenarnya.

Kualitas laba pada umumnya diproksikan dengan tingkat absolut akrual diskresioner (Discretionary Accruals) yang merupakan komponen akrual dalam kebijakan manajemen untuk melakukan intervensi dalam proses pelaporan keuangan. Dengan asumsi semakin besar nilai akrual diskresioner maka semakin besar pula manajemen laba, yang berarti semakin buruk kualitas laba.

Manajemen laba yang sah adalah yang bertindak secara konsisten dengan prinsip akuntansi yang berlaku umum (GAAP), namun manajemen laba menjadi tidak sah apabila telah melibatkan manipulasi laba dengan tujuan untuk meningkatkan pendapatan yang diharapkan.

\section{Hipotesis Penelitian}

Fraud dapat diantisipasi melalui redflags sebagai alarm/ sinyal adanya indikasi terjadinya kecurangan dalam perusahaan yang potensial terjadi. Meski demikian, tanggung jawab untuk mendeteksi kecurangan bukan sepenuhnya bagian dari auditor (eksternal) melainkan tanggung jawab manajemen perusahaan untuk mendeteksi dan mencegah fraud melalui pelaksanaan prosedur pengendalian internal. Maka untuk mendeteksi prakondisi yang memungkinkan perusahaan untuk terlibat dalam 
manipulasi terkait dengan variabel laporan keuangan Dechow, et al. (2007) merancang suatu model dengan menggunakan data akuntansi. Berdasarkan uraian diatas, maka dapat diajukan hipotesis 1 yang dirumuskan sebagai berikut :

\section{H1 : Auditor spesialisasi industri berpengaruh positif terhadap kualitas laba dalam pelaporan keuangan.}

Keberadaan auditor yang kompeten juga dapat mengurangi tingkat manajemen laba suatu perusahaan dan pengguna informasi laporan keuangan akan lebih mempercayai informasi yang disajikan. Namun, penggunaaan jasa auditor yang berpengalaman akan memiliki pengetahuan tentang kekeliruan dan kecurangan yang lebih banyak dibandingkan dengan auditor yang tidak berpengalaman (Sucipto, 2007). Perhitungan metode Craswell mengidentifikasi auditor spesialisasi industri berdasarkan pada perubahan market share. Berdasarkan uraian diatas, maka dapat diajukan hipotesis 2 yang dirumuskan sebagai berikut:

\section{H2 : Redflags dapat berpengaruh negatif terhadap kualitas laba dalam pelaporan keuangan.}

\section{METODE PENELITIAN}

Populasi dalam penelitian ini meliputi semua perusahaan publik yang terdaftar di Bursa Efek Indonesia (BEI) periode tahun 2014 - 2015. Perusahan publik yang digunakan sebagai obyek penelitian memiliki aktivitas operasional di bidang keuangan (perbankan, lembaga pembiayaan, perusahaan efek, perusahaan asuransi, dan perusahaan jasa investasi).

Hal yang mendasari pemilihan obyek penelitian pada perusahaan publik di bidang keuangan adalah karena industri keuangan memiliki karakteristik khusus. Industri keuangan dipengaruhi oleh regulasi dari pemerintah karena memiliki tingkat rasio leverage lebih tinggi dibanding dengan industri non-keuangan, sehingga likuiditas dan tingkat kecukupan modal diatur secara ketat oleh Bank Indonesia. 
Data yang dikumpulkan adalah daftar perusahaan yang terdaftar dan mempublikasikan pelaporan laporan keuangan tahunan (annual report) di Bursa Efek Indonesia. Data-data tersebut dapat diperoleha melalui situs BEI yaitu www.idx.co.id

\section{Pemilihan dan Pengukuran Variabel}

Variabel independen yang digunakan dalam penelitian ini adalah auditor spesialisasi industri dan red flags. Perhitungan terhadap identifikasi auditor spesialis industri dalam penelitian ini menggunakan metode Craswell. Metode ini dipilih karena memiliki hasil sensitif terhadap perubahan market share untuk mengidentifikasi auditor spesialisasi industri. Perhitungan metode Craswell didasarkan pada :

a. Total pendapatan klien yang diaudit dalam satu tahun dengan ketentuan auditor spesialisasi industri memiliki persentase total pendapatan klien lebih dari $15 \%$.

b. Persentase jumlah klien yang diaudit dalam satu tahun dengan ketentuan auditor spesialisasi industri memiliki persentase jumlah klien lebih dari $15 \%$.

Auditor yang akan di ukur dalam penelitian ini adalah KAP yang telah melakukan proses audit Laporan Keuangan perusahaan go public di bidang keuangan pada tahun 2014 - 2015 adalah sebanyak 28 KAP.

Pengukuran terhadap variabel redflags menggunakan rasio keuangan berdasarkan F-Score Model (Dechow et al, 2007) untuk mengidentifikasi masalah dalam pelaporan keuangan. Berikut rasio keuangan yang digunakan dalam mendeteksi red flags:

\section{$F-$ Score $=-6.753+0.773 \mathrm{TACC}+3.201 \mathrm{CIR}+2.465 \mathrm{CII}+0.108 \mathrm{CIS}-0.995 \mathrm{CIE}$}

Jika F - Score > 1 mengindikasikan adanya kemungkinan masalah di akrual, piutang, persediaan, dan penjualan tunai. Sebaliknya, jika $\mathrm{F}-$ Score $<1$ maka perusahaan tersebut diindikasikan tidak ada masalah dalam laporan keuangannya. 


\section{Tabel 1}

\section{Rasio Keuangan $\boldsymbol{F}$ - Score}

\begin{tabular}{|l|l|}
\hline \multicolumn{1}{|c|}{ Proksi F - Score Model } & \multicolumn{1}{c|}{ Perhitungan } \\
\hline TACC (Total Accrual) & $\mathrm{NI}_{\mathrm{it}-1-\mathrm{CFO}_{\mathrm{it}}}$ \\
\hline CIR (Change in Receivable) & $\Delta$ Receivable / Average total Assets \\
\hline CII (Change in Inventory) & $\Delta$ Inventory / Average total Assets \\
\hline CIS (Change in Cash Sales) & {$[(\Delta$ Sales / Sales $(\mathrm{t}))-(\Delta$ Receivable / Receivable $(\mathrm{t}))]$} \\
\hline CIE (Change in Earnings) & $\begin{array}{l}{[(\text { Earnings }(\mathrm{t}) / \text { Average total Assets }(\mathrm{t}))-(\text { Earnings }(\mathrm{t}-1) / \text { Average }} \\
\text { total assets }(\mathrm{t}-1))]\end{array}$ \\
\hline
\end{tabular}

Variabel dependen dalam penelitian ini adalah kualitas laba yang diproksikan dengan akrual diskresioner. Pengukuran akrual diskresioner yang digunakan adalah versi cross-sectional dari model Modified Jones yang relatif terbaik dalam menganalisis akrual normal perusahaan terhadap perubahan dalam penjualan dan nilai aktiva tetap perusahaan. Semakin tinggi tingkat akrual diskresioner maka semakin besar manajemen laba, yang berarti semakin buruk kualitas laba. Adapun langkah-langkahnya adalah sebagai berikut:

1. Menghitung Total Akrual.

$\mathrm{TACC}_{\mathrm{i} 1}=\mathrm{NI}_{\mathrm{it}-1}-\mathrm{CFO}_{\text {it }}$

2. Menghitung nilai accruals yang diestimasi menggunakan persamaan regresi.

$\mathrm{TACC}_{\mathrm{it}} / \mathrm{TA}_{\mathrm{it}-1}=\square_{1}\left(1 / \mathrm{TA}_{\mathrm{it}-1}\right)+\square_{2}\left(\Delta \mathrm{REV}_{\mathrm{it}} / \mathrm{TA}_{\mathrm{it}-1}\right)+\square_{\square}\left(\mathrm{PPE}_{\mathrm{it}} / \mathrm{TA}_{\mathrm{it}-1}\right)+\square_{\mathrm{it}} \ldots$

3. Menghitung tingkat akrual yang normal (Non-Discreationary Accrual) dengan menggunakan koefesien regresi di atas.

$$
\mathrm{NDAC}_{\mathrm{it}}=\square_{0}\left(1 / \mathrm{TA}_{\mathrm{it}-1}\right)+\square_{1}\left[\left(\Delta \mathrm{REV}_{\mathrm{it}}-\Delta \mathrm{AR}_{\mathrm{it}}\right) / \mathrm{TA}_{\mathrm{it}-1}\right]+\square_{2}\left(\mathrm{PPE}_{\mathrm{it}} / \mathrm{TA}_{\mathrm{it}-1}\right)+\square_{\mathrm{it}}
$$

4. Menentukan Discreationary Accrual dengan menggabungkan persamaan (2) dan (3):

$\mathrm{DAC}_{\mathrm{it}}=\mathrm{TACC}_{\mathrm{i} /} / \mathrm{TA}_{\mathrm{it}-1}-\mathrm{NDAC}_{\mathrm{it}}$ 


\section{Dimana :}

$\mathrm{TACC}_{\mathrm{it}}=$ total akrual perusahaan i untuk tahun $\mathrm{t}$.

$\mathrm{NI}_{\text {it }} \quad=$ laba bersih sebelum pajak perusahaan i untuk tahun $\mathrm{t}$.

$\mathrm{CFO}_{\text {it }} \quad=$ cash flow perusahaan i untuk tahun $\mathrm{t}$.

$\mathrm{TA}_{\mathrm{it}-1}=$ total aset perusahaan i untuk tahun $\mathrm{t}-1$.

$\mathrm{DAC}_{\mathrm{it}}=$ discretionary accrual perusahaan i untuk tahun $\mathrm{t}$.

$\mathrm{NDAC}_{\mathrm{it}}=$ non-discretionary accrual perusahaan i untuk tahun $\mathrm{t}$.

$\Delta \mathrm{REV}_{\mathrm{it}}=$ Perubahan pendapatan perusahaan $\mathrm{i}$ untuk tahun $\mathrm{t}$ dikurangi pendapatan untuk tahun $\mathrm{t}-1$

$\Delta \mathrm{AR}_{\mathrm{it}} \quad=$ Perubahan piutang bersih perusahaan $\mathrm{i}$ untuk tahun $\mathrm{t}$ dikurangi piutang untuk tahun $\mathrm{t}-1$

$\mathrm{PPE}_{\text {it }} \quad=$ nilai aktiva tetap perusahaan i pada tahun $\mathrm{t}$.

$\varepsilon_{\mathrm{it}} \quad=$ residual perusahaan i pada tahun $\mathrm{t}$.

Variabel kontrol yang digunakan dalam penelitian ini, antara lain :

a. Total aset perusahaan (LTA) adalah nilai logaritma dari total aset dan mewakili untuk ukuran perusahaan.

b. Tingkat leverage perusahaan (LVGI) adalah rasio total utang terhadap total aset. Tingkat leverage menggambarkan kemampuan perusahaan dalam membayar semua kewajiban jangka panjang maupun jangka pendek.

\section{Teknik dan Langkah Analisis}

Model penelitian ini menggunakan analisis regresi berganda yang bertujuan untuk memprediksi perubahan hubungan beberapa variabel independen dan variabel dependen, serta melakukan uji asumsi klasik dengan uji normalitas, autokorelasi, 
heteroskedasititas, dan multikolinearitas. Tingkat kepercayaan yang digunakan adalah $95 \%$.

Adapun persamaan regresi yang digunakan untuk menguji hipotesis adalah sebagai berikut :

$$
\operatorname{Abs}(\mathbf{D A C i t})=\alpha_{0}+\alpha_{1} \text { SP_1it }+\alpha_{2} \text { Sp_2it }+\alpha_{3} \text { FM.it }+\alpha_{4} \text { LTAit }+\alpha_{5} \text { LVGIt }+\alpha_{i t}
$$

Keterangan :

Abs $\left(\mathrm{DAC}_{\mathrm{it}}\right)=$ nilai absolut dari DAC perusahaan i pada waktu $\mathrm{t}$.

SP_1 $1_{\text {it }} \quad=$ auditor spesialisasi industri berdasarkan jumlah klien i pada waktu $\mathrm{t}$.

SP_2 $\quad=$ auditor spesialisasi industri berdasarkan pendapatan klien $\mathrm{i}$ pada waktu t.

$\mathrm{FM}_{\mathrm{it}} \quad=$ redflags $(F-$ Score Model $)$ perusahaan i pada waktu $\mathrm{t}$.

LTA $_{\text {it }} \quad=\log$ dari total aset sebagai ukuran perusahaan i pada waktu $\mathrm{t}$.

LVGI $_{\text {it }} \quad$ = rasio utang jangka panjang terhadap aktiva perusahaan i pada waktu $\mathrm{t}$.

$\varepsilon \quad=$ error.

\section{HASIL PENELITIAN DAN PEMBAHASAN}

\section{Statistik Deskriptif}

Dalam penelitian ini menggunakan purposive sampling method dengan kriteria dan karakteristik yang telah ditentukan dengan jangka waktu penelitian yang diamati selama dua tahun yaitu 2014 dan 2015. Jumlah sampel perusahaan yang digunakan adalah 121 emiten. Pada Tabel 2 disajikan statistik deskriptif untuk variabel-variabel yang diteliti . 
Tabel 2.

Statisti Deskriptif

\begin{tabular}{|l|r|r|r|r|r|}
\hline & \multicolumn{1}{|c|}{ Mean } & \multicolumn{1}{c|}{ Min } & \multicolumn{1}{c|}{ Max } & Std Dev & \multicolumn{1}{c|}{ N } \\
\hline Log_DAC & -1.3442 & -3.1537 & -0.5815 & 0.4569 & 121 \\
SPEC_1 & 0.0875 & 0.0108 & 0.2258 & 0.0757 & 121 \\
SPEC_2 & 0.1387 & -0.0046 & 0.6104 & 0.2129 & 121 \\
F_Score & -6.4716 & -8.1173 & -4.7949 & 0.4244 & 121 \\
LTA & 12.7315 & 10.7101 & 14.9591 & 0.9444 & 121 \\
LVGI & 0.6043 & 0.0071 & 0.9479 & 0.2868 & \\
\hline
\end{tabular}

Variabel akrual diskresioner mempunyai nilai terendah sebesar $-3,1537$ terjadi pada Bank Bukopin Tbk. pada tahun 2015, yang berarti memiliki kualitas laba yang baik. Sedangkan, perusahaan yang memiliki akrual diskresioner tertinggi pada PT. Panin Sekuritas Tbk. sebesar -0,5815 pada tahun 2014 yang artinya memiliki kualitas laba yang buruk.

Variabel auditor spesialisasi industri $\left(\mathrm{X}_{1}\right)$ yang berdasarkan jumlah klien mempunyai nilai terendah sebesar 0,0108 artinya perusahaan yang tidak diaudit oleh auditor spesialisasi industri sebanyak 9 emiten dan semuanya pada tahun 2015. Nilai tertingginya sebesar 0,2258 terdapat pada 15 emiten di tahun 2015. Data untuk auditor $\mathrm{X}_{1}$ diperoleh bahwa terdapat 28 perusahaan atau $23 \%$ menggunakan jasa auditor spesialisasi industri.

Tabel 3.

Hasil Distribusi Frekuensi Auditor Spesialisasi Industri Berdasarkan Jumlah Klien

\begin{tabular}{|l|c|c|}
\hline & PERUSAHAAN & PERSENTASE \\
\hline SPESIALISASI INDUSTRI & 28 & $23 \%$ \\
NON-SPESIALISASI INDUSTRI & 93 & $77 \%$ \\
\hline & 121 & $100 \%$ \\
\hline
\end{tabular}


Variabel auditor spesialisasi industri $\left(\mathrm{X}_{2}\right)$ yang berdasarkan pendapatan klien mempunyai nilai terendah sebesar -0,0046 sebanyak 2 emiten di tahun 2015 yaitu Bank Jtrust Indonesia Tbk dan PT. Victoria Insurance Tbk. Nilai tertingginya sebesar 0,6104 terdapat pada 15 emiten di tahun 2015 yaitu perusahaan yang diaudit spesialisasi industri karena memiliki persentase pendapatan klien setahun lebih dari 15\%. Data untuk auditor $\mathrm{X}_{2}$ diperoleh bahwa terdapat 35 perusahaan atau $29 \%$ menggunakan jasa auditor spesialisasi industri

Tabel 4.

Hasil Distribusi Frekuensi Auditor Spesialisasi Industri

Berdasarkan Pendapatan Klien

\begin{tabular}{|l|c|c|}
\hline & PERUSAHAAN & PERSENTASE \\
\hline SPESIALISASI INDUSTRI & 35 & $29 \%$ \\
NON-SPESIALISASI INDUSTRI & 86 & $71 \%$ \\
\hline & 121 & $100 \%$ \\
\hline
\end{tabular}

Variabel redflags $\left(\mathrm{X}_{3}\right)$ yang menggunakan $\mathrm{F}$ - Score mempunyai nilai terendah sebesar -8,1173 pada PT. Lippo Securities Tbk. dan nilai tertingginya sebesar $\quad-4,7949$ pada PT. MNC Kapital Tbk. Namun nilai terendah dan tertinggi yang dihasilkan F-Score $<1$, maka perusahaan tersebut diindikasikan tidak memiliki masalah dalam laporan keuangannya.

Variable kontrol LTA mewakili untuk ukuran perusahaan mempunyai nilai terendah sebesar -10,7101 adalah PT. Danasupra Erapacific Tbk dan nilai tertinggi sebesar 14,9591 pada PT. Bank Mandiri (Persero) Tbk.

Variable kontrol LVGI yang mendeskripsikan kemampuan perusahaan dalam membayar semua kewajiban menunjukan memiliki nilai terendah sebesar 0,0071 yaitu PT. Lippo Securities Tbk. Sedangkan, nilai tertinggi sebesar 0,9479 dimiliki oleh PT. Bank Pembangunan Daerah Banten Tbk. 


\section{Uji Asumsi Klasik}

1) Uji Normalitas

Hasil uji normalitas yang berdasarkan dengan Kolmogorov-Smirnov Test nampak pada tabel 2 bahwa residual data setelah transformasi data telah terdistrubusi normal karena memiliki nilai signifikansi $>0,05$.

Tabel 5.

Uji Normalitas

\begin{tabular}{|c|c|c|}
\hline & & $\begin{array}{l}\text { Unstandardized } \\
\text { Residual }\end{array}$ \\
\hline $\mathrm{N}$ & & 121 \\
\hline \multirow[t]{2}{*}{ Normal Parameters ${ }^{\mathrm{a}}$} & Mean & 0.000 \\
\hline & Std. Deviation & 0.411 \\
\hline \multirow[t]{3}{*}{ Most Extreme Differences } & Absolute & 0.104 \\
\hline & Positive & 0.079 \\
\hline & Negative & -0.104 \\
\hline Kolmogorov-Smirnov Z & & 1.139 \\
\hline Asymp. Sig. (2-tailed) & & 0.149 \\
\hline
\end{tabular}

Gambar 1. Normal Probability Plot

Normal P-P Plot of Regression Standardized Residual

Dependent Variable: Log_DAC

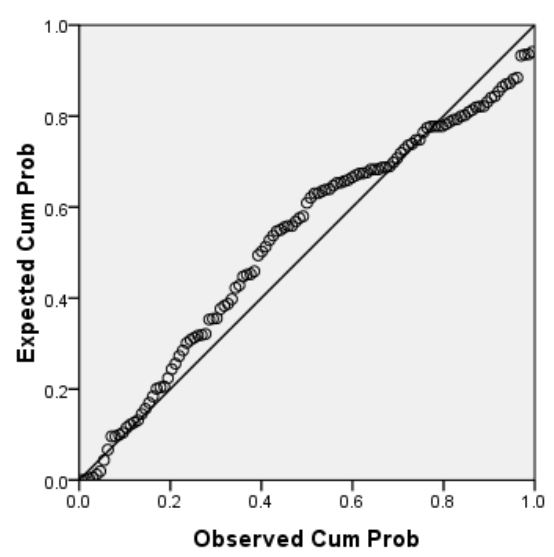


Berdasarkan pada gambar grafik di atas terlihat pada titik-titik penyebaran di sekitar garis diagonal dan penyebarannya mengikuti arah garis diagonal, maka model regresi ini layak dipakai untuk memprediksikan akrual diskresioner.

2) Uji Multikolinearitas

Hasil pengujian multikolinearitas ditunjukan pada tabel 6 berikut :

Tabel 6.

\section{Uji Multikolinearitas}

\begin{tabular}{|l|r|r|}
\hline \multirow{2}{*}{ Model } & \multicolumn{2}{|c|}{ Collinearity Statistics } \\
\cline { 2 - 3 } & Tolerance & \multicolumn{1}{c|}{ VIF } \\
\hline SPEC_1 & 0.230 & 4.343 \\
SPEC_2 & 0.221 & 4.529 \\
REDFLAGS & 0.975 & 1.025 \\
LTA & 0.596 & 1.678 \\
LVGI & 0.573 & 1.746 \\
\hline
\end{tabular}

Pada hasil uji multikolinearitas terlihat semua nilai VIF antar variabel independen < 10 dan nilai tolerance $>0,1$. Hal ini menunjukkan tidak terjadi gejala multikolinearitas pada penelitian ini.

3) Uji Heterokedastisitas

Uji heterokedastisitas melalui uji Glejser dilakukan dengan cara meregresikan antara variabel independen dengan nilai absolut residualnya. 
Tabel 7.

Uji Glejser

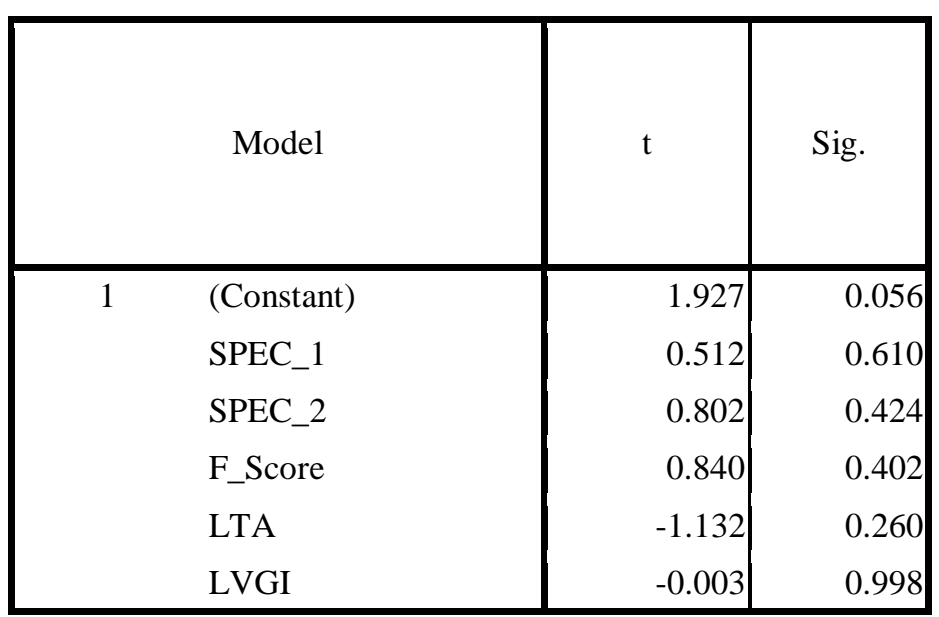

Maka dapat diketahui bahwa nilai signifikansi masing-masing variabel independen $>\alpha(0,05)$ yang berarti bahwa tidak terjadi masalah heterokedastisitas pada model regresi yang digunakan dalam penelitian ini.

Gambar 2.

Scatterplot

\section{Scatterplot}

Dependent Variable: Log_DAC

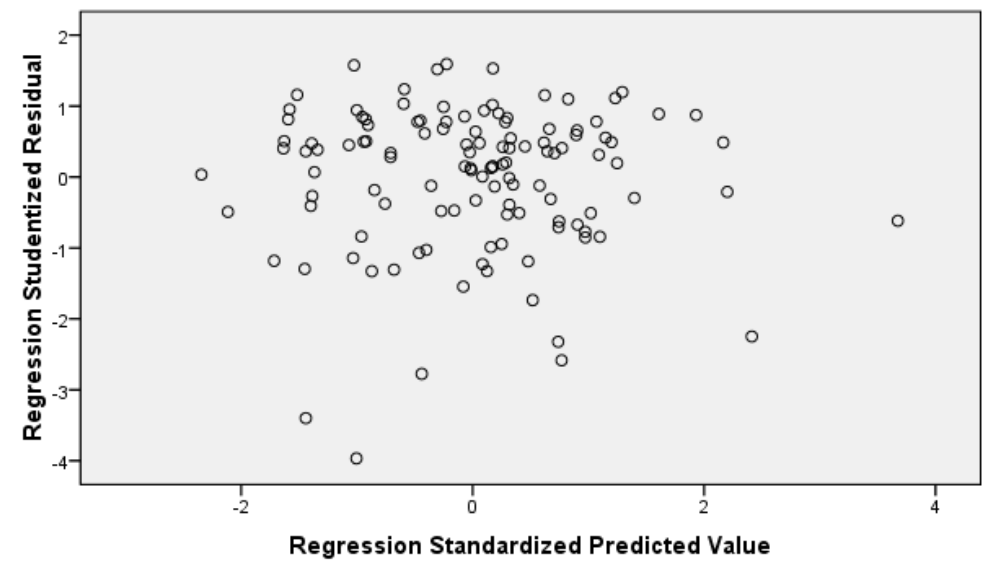


Menurut gambar scartterplot di atas menunjukan adanya titik-titik penyebaran secara acak dan tidak membentuk sebuah pola tertentu yang jelas. Penyebarannya pun nampak berada di atas dan di bawah angka nol pada sumbu Y. Maka hal ini menunjukan bahwa tidak terjadi heteroskedastisitas pada penelitian ini.

\section{4) Uji Autokorelasi}

Hasil pengujian autokorelasi dengan menggunakan model Durbin Watson (DW) ditunjukan pada tabel 8 berikut :

Tabel 8.

Uji Autokorelasi

\begin{tabular}{|c|c|c|c|c|}
\hline $\mathrm{R}$ & $\mathrm{R}^{2}$ & $\begin{array}{c}\text { Adjusted } \\
\mathrm{R}^{2}\end{array}$ & $\begin{array}{c}\text { Std. } \\
\text { Error }\end{array}$ & Durbin-Watson \\
\hline $0.466^{\mathrm{a}}$ & 0.217 & 0.183 & 0.41297 & $\mathbf{1 . 8 7 6}$ \\
\hline
\end{tabular}

Berdasarkan hasil perhitungan pada tabel diatas nilai $d \mathrm{~W}$ diketahui sebesar 1,876 dengan nilai $d \mathbf{U}$ sebesar 1,802 dan nilai 4- $d \mathbf{U}$ adalah 2,198. Maka dapat disimpulkan apabila $d \mathrm{U}<d \mathrm{~W}<4-d \mathrm{U}$ artinya tidak terdapat autokorelasi.

\section{Hasil Analisis dan Pengujian Hipotesis}

Berdasarkan tabel 9 dapat dilihat bahwa nilai signifikan adalah 0,000 dan dengan menentukan tingkat kesalahan 5\% derajat kebebasan $\mathrm{df}_{1}=5$ dan $\mathrm{df}_{2}=115$ maka diperoleh dari tabel $F_{\text {tabel }}=2,29$. Oleh karena $F_{\text {hitung }}>F_{\text {tabel }}$ dan nilai signifikasi lebih kecil dari taraf signifikansi 0,05 Maka dapat disimpulkan bahwa variabel auditor spesialisasi industri dan redflags secara simultan berpengaruh signifikan terhadap variabel kualitas laba. 


\section{Tabel 9.}

Uji F

\begin{tabular}{|c|c|c|c|c|c|}
\hline & Model & Sum of Squares & $\mathrm{df}$ & $\mathrm{F}$ & Sig. \\
\hline \multirow[t]{3}{*}{1} & Regression & 5.439 & 5 & 6.379 & $0.000^{\mathrm{a}}$ \\
\hline & Residual & 19.613 & 115 & & \\
\hline & Total & 25.052 & 120 & & \\
\hline
\end{tabular}

Tabel 10.

Uji Koefesien Determinasi

\begin{tabular}{|c|c|c|c|c|c|}
\hline \multirow{2}{*}{ Model } & $\mathrm{R}$ & $\mathrm{R}$ Square & $\begin{array}{c}\text { Adjusted R } \\
\text { Square }\end{array}$ & $\begin{array}{c}\text { Std. Error of the } \\
\text { Estimate }\end{array}$ & Durbin-Watson \\
\hline 1 & $0.466^{\mathrm{a}}$ & $\mathbf{0 . 2 1 7}$ & 0.183 & 0.41297 & 1.876 \\
\hline
\end{tabular}

Hasil regresi pada tabel 10 diatas dapat diketahui bahwa nilai $R^{2}$ sebesar 0,217 atau 21,7\%. Hal ini mengindikasikan bahwa variabel auditor spesialisasi industri dan variabel redflags dalam penelitian ini hanya mampu menjelaskan variabel kualitas laba sebanyak $21,7 \%$, sedangkan sisanya $78,3 \%$ dijelaskan oleh variabel lain yang tidak dimasukkan dalam penelitian ini.

Tabel 11.

Hasil Analisis

\begin{tabular}{|c|c|c|c|c|c|}
\hline & \multirow[t]{2}{*}{ Model } & \multicolumn{2}{|c|}{$\begin{array}{l}\text { Unstandardized } \\
\text { Coefficients }\end{array}$} & \multirow[t]{2}{*}{$\mathrm{t}$} & \multirow[t]{2}{*}{ Sig. } \\
\hline & & B & Std. Error & & \\
\hline \multirow[t]{6}{*}{1} & (Constant) & 1.103 & 0.855 & 1.290 & 0.200 \\
\hline & SPEC_1 & -1.054 & 1.037 & -1.884 & 0.062 \\
\hline & SPEC_2 & 0.193 & 0.377 & 0.513 & 0.609 \\
\hline & F_Score & 0.367 & 0.090 & 4.081 & 0.000 \\
\hline & LTA & 0.021 & 0.052 & 0.413 & 0.680 \\
\hline & LVGI & -0.331 & 0.174 & -1.905 & 0.059 \\
\hline
\end{tabular}


Berdasarkan pada tabel 9 maka diperoleh persamaan regresi berganda sebagai berikut:

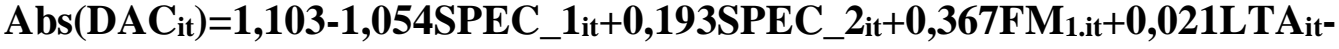 0.331LVGIit}

Hubungan antara variabel independen terhadap variabel dependen secara parsial dapat dijelaskan sebagai berikut :

\section{Pengaruh Auditor Spesialisasi Industri terhadap Kualitas Laba}

Auditor spesialisasi industri berdasarkan jumlah klien (SPEC_1) memiliki tingkat signifikan sebesar 0,062 lebih besar dari taraf signifikansi 0,05 (5\%) dan memiliki thitung $(-1,884)$ lebih kecil dari $t_{\text {tabel }}(1,982)$. Apabila variabel auditor spesialisasi industri ke - 1 naik satu satuan dengan asumsi variabel yang lain konstan, sehingga nilai akrual diskresioner menjadi 0,0490. Hubungan akrual diskresioner dengan kualitas laba adalah berbanding terbalik, sehingga variabel auditor spesialisasi industri ke - 1 berpengaruh negatif terhadap kualitas laba.

Sedangkan, auditor spesialisasi industri berdasarkan pendapatan klien (SPEC_2) memiliki tingkat signifikan sebesar 0,609 lebih besar dari taraf signifikansi 0,05 (5\%) dan memiliki $t_{\text {hitung }}$ yaitu 0,513 lebih kecil dari $t_{\text {tabel }}(1,982)$. Apabila variabel auditor spesialisasi industri ke - 2 naik satu satuan dengan asumsi variabel yang lain konstan, sehingga nilai akrual diskresioner menjadi 1,2960. Hubungan akrual diskresioner dengan kualitas laba adalah berbanding terbalik, sehingga variabel auditor spesialisasi industri ke - 2 berpengaruh negatif terhadap kualitas laba.

Maka dapat disimpulkan bahwa hasil penelitian ini tidak sesuai dengan hipotesis yang telah dibuat (H1) yaitu auditor spesialiasasi industri tidak berpengaruh terhadap kualitas laba. Dengan demikian hipotesis pertama (H1) ditolak. Hasil penelitian ini berbeda dengan hasil penelitian Viva dan Tarmizi (2012) dengan menggunakan $F$ Score Model menentukan keberadaan KAP yang kompeten mampu menurunkan risiko terjadinya kecurangan dalam pelaporan keuangan. 


\section{Pengaruh Redflags terhadap Kualitas Laba}

Variable redflags (F_Score) memiliki tingkat signifikan sebesar 0,000 lebih kecil dari taraf signifikansi 0,05 (5\%) dan memiliki thitung yaitu 4,081 lebih besar dari $t_{\text {tabel }}$ $(1,982)$. Hal ini menunjukan bahwa redflags berpengaruh signifikan terhadap kualitas laba. Apabila variabel redflags naik satu satuan maka nilai akrual diskresioner meningkat sebesar 0,062 dengan asumsi variabel yang lain konstan, sehingga nilai akrual diskresioner menjadi 1,470. Hubungan akrual diskresioner dengan kualitas laba adalah berbanding terbalik, sehingga redflags berpengaruh negatif terhadap kualitas laba. Maka dapat disimpulkan bahwa hasil penelitian ini sesuai dengan hipotesis yang telah dibuat (H2) bahwa redflags berpengaruh signifikan dan negatif terhadap kualitas laba, sehinggadengan demikian hipotesis kedua (H2) diterima.

Hasil penelitian ini sesuai dengan hasil penelitian Moyes, et al. (2009) yang menggunakan indikator - indikator redflags untuk mendeteksi kecurangan dalam akuntansi keuangan, namun berbeda pendapat dengan penelitian Guan, et al. (2008) yang bahwa analisa rasio keuangan tidak efektif dalam mendeteksi penyimpangan dalam laporan keuangan.

\section{PENUTUP}

\section{Kesimpulan}

Berdasarkan pembahasan hasil analisis dan pembahasan yang telah dikemukakan sebelumnya maka dapat disimpulkan bahwa dalam penelitian ini peranan auditor spesialisasi industri tidak berpengaruh signifikan terhadap kualitas laba indikator redflags berpengaruh signifikan terhadap kualitas laba pada perusahaan di sektor keuangan yang terdaftar di Bursa Efek Indonesia periode tahun 2014 - 2015.

Hal ini nampak pada indikator redflags pada semua sampel penelitian saat penghitungan $F$-Score yang menunjukkan nilai $<1$ yang berarti tidak memiliki masalah dalam laporan keuangannya. Manajemen keuangan setiap perusahaan di bidang keuangan berada dalam pengawasan yang ketat oleh pihak Bank Indonesia, sehingga adanya auditor spesialisasi industri kurang berperan dalam menciptakan kualitas laba yang relevan dan baik. 


\section{Saran dan Keterbatasan}

Berdasarkan kesimpulan yang telah diberikan, peneliti dapat memberikan saran saran sebagai berikut :

1. Penelitian selanjutnya dapat menggunakan variabel independen yang berbeda dengan memasukan faktor lain yang mungkin dapat mempengaruhi kualitas laba.

2. Variabel dependen yang mempengaruhi kualitas laba selain DAC dapat dimasukan dalam penelitian.

Penelitian ini memiliki beberapa keterbatasan antara lain :

1) Pengukuran auditor spesialisasi industri selain menggunakan metode Craswell berdasarkan jumlah klien dan total aset perusahaan, dapat juga menggunakan pendekatan Market Share.

2) Pengukuran redflags selain menggunakan rasio keuangan $F$-Score milik Dechow dapat menggunakan rasio keuangan lainnya.

3) Subyektivitas peneliti mempengaruhi dalam memahami laporan keuangan.

\section{DAFTAR PUSTAKA}

Anggriawan. 2014. "Pengaruh Pengalaman Kerja, Skeptisme Profesional dan Tekanan Waktu terhadap Kemampuan Auditor dalam Mendeteksi Fraud (Studi Empiris pada Kantor Akuntan Publik di DIY)." Jurnal Nominal Vol. III, 2

Dechow, Ge, W., Larson, C., R.G.Sloan. 2007. "Predicting Material Accounting Misstatements.” Comporary Accounting Research Vol. 28 No.1, 17-82

Dechow, Hutton, J.H. Kim, dan R.G.Sloan. 2011. "Detecting Earnings Management : A New Approach." Journal of Accounting and Economics, 50

Deegan. 2007. "Financial Accounting Theory:2nd Edition." Mc-Graw Hill. Australia

Dichev, Graham, C.R.Harvey dan S.Rajgopal. 2012. "Earnings Quality: Evidence from The Field.” Working Paper. Goizueta Business School, Emory University 
Guan., K.A.Kaminski dan Wetzel. 2008. "Can Investors Detect Fraud Using Financial Statements: An Exploratory Study.” Managerial Auditing Journal, 19(1). Emerald Group Publishing Limited

Moyes, G.D., Shao, dan M. Newsome. 2009. "Analyzing The Effectiviness of Red Flags to Detect Fraudulent Financial Reporting." Journal of Business and Economics, 9

Santoso, S.,2001. “SPSS Statistik Parametrik: Edisi ke Dua.” Gramedia. Jakarta.

Schilit, H.M. dan Perler. 2010. "Financial Shenanigans Third Edition: How to Detect Accounting Gimick and Fraud in Financial Reports." New York: McGraw-Hill, Inc.

Scott, W. 2009. “Financial Accounting Theory : 3rd Edition.” Canada. Prentice Hall.

Sonnier, B.M, Carson, K.D, dan Carson, P.P. 2009. “An Examination of The Impact of Firm Size and Age on Managerial Disclosure of Intellectual Capital by High-Tech Companies.” Journal of Business Strategies

Sucipto. 2007. "Penilaian Kinerja Keuangan.” Jurnal Akuntansi Universitas Sumatra Utara. Medan

Viva, Y. dan Tarmizi A., 2012. "Analisis Prediksi Potensi Risiko Fraudulent Financial Statement melalui Fraud Score Model." Jurnal of Accounting Vol. 1. Universitas Diponegoro

Yamin, S. dan Kurniawan, H. 2013. "SPSS Complete Tehnik Analisis Statistik Terlengkap dengan Software SPSS : Edisi 2.” Salemba Infotek. Jakarta 